\title{
Maximal histalog test in control subjects and patients with peptic ulcer
}

\author{
KENNETH G. WORMSLEY AND MORTON I. GROSSMAN \\ From the Veterans Administration Centre and University of California \\ School of Medicine, Los Angeles, California, U.S.A.
}

EDITORIAL SYNOPSIS This is a very valuable detailed analysis of the maximal histalog test. The studies suggest that increased parietal cell mass in duodenal ulcer is unlikely to be the most important factor in its pathophysiology. It was noted that impaired secretory capacity suggesting mucosal damage is associated with peptic ulcer in a considerable proportion of patients of all categories.

Previous studies have established the dose of histalog required to produce maximal stimulation of acid secretion (Ward, Gillespie, Passaro, and Grossman, 1963; Zaterka and Neves, 1964). In the present investigation, maximal stimulation with histalog was used to compare gastric function in patients with peptic ulcer and in control subjects.

\section{METHODS}

Each patient to be tested was fasted overnight and in the morning had a tube (16F) passed through the nose. The position of the tube was checked fluoroscopically. The patient remained seated throughout the test. Saliva was expectorated when necessary. Gastric juice was aspirated continuously and mechanically at $30 \mathrm{~mm}$. $\mathrm{Hg}$ subatmospheric pressure, with automatic switch-off for 10 out of every $\mathbf{6 0}$ seconds. All tests were performed by the same technician.

After removal of the residual juice, basal secretion was aspirated for one hour. Histalog (Betazole, 3-beta aminoethylpyrazole dihydrochloride, Lilly) was then injected subcutaneously in a dose of $1.5 \mathrm{mg}$. per $\mathrm{kg}$. body weight. A dose of this order had been found to evoke maximal secretion in similar patients (Ward et al., 1963) and in a recent report from Brazil (Zaterka and Neves, 1964). The stimulated secretion was aspirated in eight quarter hourly periods. In 12 subjects the whole test was done again within 14 days, in order to assess repeatability.

A sample of the aspirated juice was titrated electrometrically to $p \mathrm{H} 7 \cdot 0$, using $0 \cdot 2 \mathrm{~N}$ sodium hydroxide with an autoburette titrator and $p \mathrm{H}$ meter (Radiometer, Copenhagen, Denmark).

PATIENTS The patients were male veterans (Table I). The control group comprised patients from the surgical services who were suffering from inguinal hernias, varicose veins and other minor non-alimentary dis-

\section{TABLE I}

AGE DISTRIBUTION OF PATIENTS HAVING MAXIMAL HISTALOG TESTS

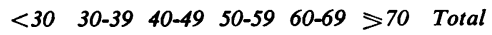

\begin{tabular}{|c|c|c|c|c|c|c|c|}
\hline Controls & 6 & 15 & 15 & 18 & 14 & 7 & 75 \\
\hline Duodenal ulcer & 9 & 23 & 42 & 22 & 13 & 8 & 117 \\
\hline $\begin{array}{l}\text { Duodenal + gastric } \\
\text { ulcer }\end{array}$ & 0 & 0 & 9 & 3 & 8 & 4 & 24 \\
\hline $\begin{array}{l}\text { Prepyloric ulcer } \\
\text { Corpus ulcer }\end{array}$ & $\begin{array}{l}1 \\
0\end{array}$ & $\begin{array}{l}4 \\
2\end{array}$ & $\begin{array}{r}10 \\
7\end{array}$ & $\begin{array}{l}8 \\
3\end{array}$ & $\begin{array}{r}10 \\
6\end{array}$ & $\begin{array}{l}2 \\
3\end{array}$ & $\begin{array}{l}34 \\
21\end{array}$ \\
\hline Total & 16 & 44 & 83 & 54 & 51 & 24 & 272 \\
\hline
\end{tabular}

abilities, and patients from the medical services admitted for investigation of epilepsy or convalescing from pneumonia and other miscellaneous non-alimentary illnesses. None of the control patients had ever had symptoms suggesting peptic ulcer.

Unequivocal clinical and radiological evidence was present in all patients with ulcer. Patients with gastric ulcer were classified radiologically into those with ulcers proximal or distal to a line dropped vertically from the incisura. To assess the influence of duration of illnesses, patients were considered to have 'acute' ulcers if their history was shorter than six months, and 'chronic' ulcers if symptoms had been present longer than five years. Subjects with symptoms of intermediate duration were designated as an 'intermediate' group (Table II).

STATISTICAL METHODS For purposes of comparison, the secretory response to histalog was expressed as peak 30 minute, peak 60 minute, and one and three quarter hour periods. The first quarter hour following the injection of histalog was omitted from the analysis because secretion during this period was very variable, presumably due to factors not related to gastric secretory function, such as rate of absorption from the site of injection. The peak concentration was the maximal acid concentration reached in any of the 15-minute samples. The mean concentration was the average concentration during the final seven periods after injection of histalog. 
TABLE II

DURATION OF DISEASE OF PATIENTS WITH DUODENAL ULCER

\begin{tabular}{|c|c|c|c|c|c|c|c|c|c|c|c|c|c|c|c|c|c|c|c|c|}
\hline \multicolumn{3}{|c|}{$<30$} & \multicolumn{3}{|c|}{$30-39$} & \multicolumn{3}{|c|}{$40-49$} & \multicolumn{3}{|c|}{$50-59$} & \multicolumn{3}{|c|}{$60-69$} & \multicolumn{3}{|c|}{$>70$} & \multicolumn{3}{|c|}{ Total } \\
\hline$a$ & $i$ & $c$ & $a$ & $i$ & $c$ & $a$ & $i$ & $c$ & $a$ & $i$ & $c$ & $a$ & $i$ & $c$ & $a$ & $i$ & $c$ & $a$ & $i$ & $c$ \\
\hline 2 & 2 & 5 & 5 & 3 & 15 & 6 & 2 & 34 & 5 & 2 & 15 & 5 & 3 & 5 & 2 & 0 & 6 & 25 & 12 & 80 \\
\hline
\end{tabular}

The statistical significance of the difference in distribution of secretory values in the various groups or subgroups was determined by use of the Mann-Whitney ' $U$ ' test (Siegel, 1956). The upper limit of normal was determined by the method of Herrera (1958). Using the criterion that there be a $95 \%$ probability of excluding no more than $5 \%$ of normals, the required rank number turned out to be the highest observed value of our control group and this was therefore taken as cut-off point. This criterion for setting the upper limit of normal differs from the one used in previous studies (Grossman, 1960; Grossman, Kirsner, and Gillespie, 1963). Linear regression equations were determined by the method of Bartlett (1949), since both variables being analysed were subject to error.

In the text and tables, $\mathrm{p}$ values greater than 0.05 are considered not significant.

\section{RESULTS}

No patient in the control group or with peptic ulcer failed to respond to histalog. Repeatability of all indices of stimulated secretion was excellent (Table III). Repeatability was as good in patients with low output as in those with greater response (Fig. 1).

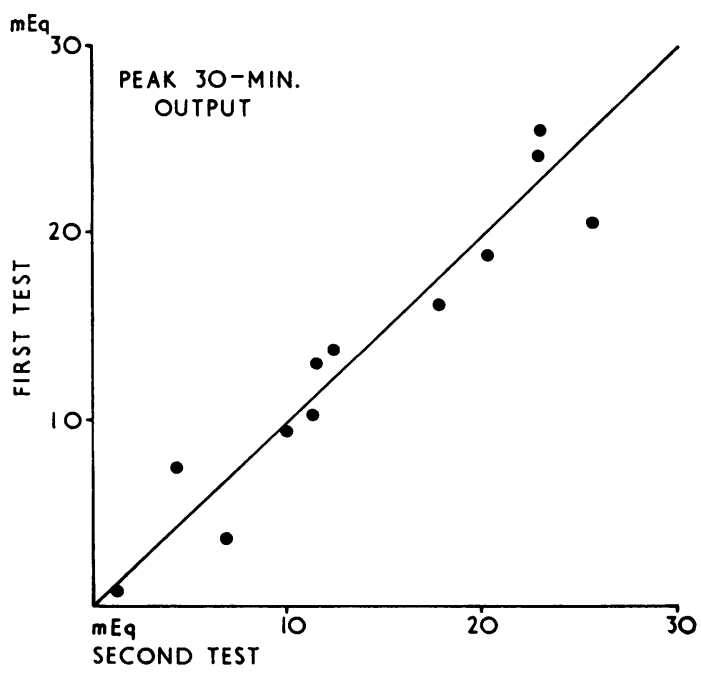

FIG. 1. Duplicate histalog tests in 12 patients, 11 with duodenal ulcer.
TABLE III

CORRELATION OF DUPLICATE SECRETORY DATA

Secretory Data Correlation

Coefficient $(r)$

$\begin{array}{ll}\text { Basal } & \\ \text { Output } & 0.58 \\ \text { Volume } & 0.62 \\ \text { Concentration } & 0.60 \\ & \\ \text { Histalog response } & \\ \text { 30-minute output } & 0.93 \\ \text { 30-minute volume } & 0.94 \\ \text { 60-minute output } & 0.97 \\ \text { 60-minute volume } & 0.96 \\ \text { One and three quarter-hour } & 0.98 \\ \text { output } & \\ \text { One and three quarter-hour } & 0.97 \\ \text { volume } & \\ \text { Peak concentration } & 0.95 \\ \text { Mean concentration } & 0.92\end{array}$

Duplicate basal secretion of 41 patients, comprising six controls, five patients with gastric ulcer and 30 with duodenal ulcer. Duplicate histalog tests in 12 patients, 11 of whom had duodenal ulcer.

CONTROLS Values for basal output and concentration were lower, but the response to histalog was greater (Table IV) than values in previously recorded studies of the augmented histamine test (Table V).

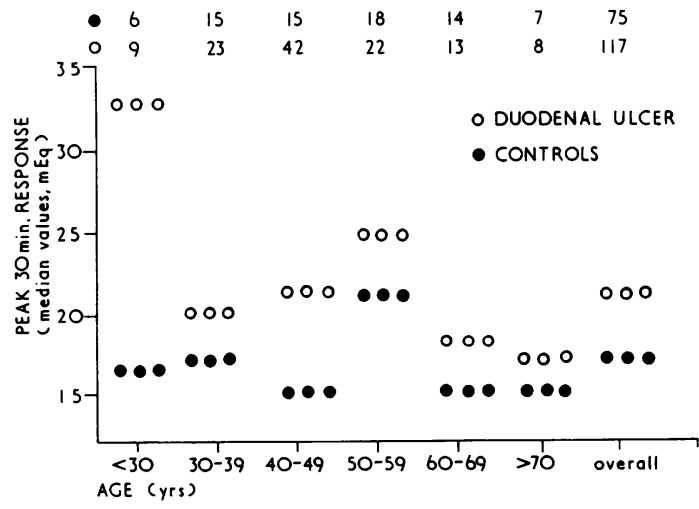

FIG. 2. Peak 30-minute response to histalog of controls and patients with duodenal ulcer, showing median values for each decade. The values for patients with duodenal ulcer below 30 years and above 60 years differ significantly from the remainder of the group. 
TABLE IV

SECRETORY DATA FOR CONTROLS AND PATIENTS WITH PEPTIC ULCER

\begin{tabular}{|c|c|c|c|c|c|c|c|c|c|c|c|c|c|c|c|}
\hline \multirow[t]{2}{*}{ Secretory Data } & \multicolumn{3}{|c|}{75 Controls } & \multicolumn{3}{|c|}{$\begin{array}{l}117 \text { Patients with } \\
\text { Duodenal Ulcer }\end{array}$} & \multicolumn{3}{|c|}{$\begin{array}{l}24 \text { Patients with } \\
\text { Duodenal }+ \text { Gastric } \\
\text { Ulcer }\end{array}$} & \multicolumn{3}{|c|}{$\begin{array}{l}35 \text { Patients with } \\
\text { Prepyloric Ulcer }\end{array}$} & \multicolumn{3}{|c|}{$\begin{array}{l}21 \text { Patients with } \\
\text { Corpus Ulcer }\end{array}$} \\
\hline & Mean & Median & $\begin{array}{l}\text { Upper }^{1} \\
\text { Limit of } \\
\text { Normal }\end{array}$ & Mean & Median & $\begin{array}{l}\text { Upper } \\
\text { Limit of } \\
\text { Normal }\end{array}$ & Mean & Median & $\begin{array}{l}\text { Upper } \\
\text { Limit of } \\
\text { Normal }\end{array}$ & Mean & Median & $\begin{array}{l}\text { Upper } \\
\text { Limit of } \\
\text { Normal }\end{array}$ & Mean & Median & $\begin{array}{l}\text { Upper } \\
\text { Limit of } \\
\text { Normal }\end{array}$ \\
\hline \multicolumn{16}{|l|}{ Basal Secretion } \\
\hline Output (mEq.) & 1.8 & $1 \cdot 4$ & $10 \cdot 2$ & $2 \cdot 1$ & $1 \cdot 4$ & 1 & $1 \cdot 8$ & 0.8 & 0 & $1 \cdot 1$ & 0.2 & 0 & $1 \cdot 5$ & 0.7 & 0 \\
\hline Volume (ml.) & 58 & 50 & 240 & 64 & 60 & 1 & 50 & 40 & $\mathbf{0}$ & 50 & 38 & 0 & 50 & 41 & 0 \\
\hline Concentration (mEq./1.) & 31 & 28 & 96 & 30 & 23 & 1 & 29 & 23 & 0 & 18 & 14 & 0 & 26 & 19 & $\mathbf{0}$ \\
\hline \multicolumn{16}{|l|}{ Stimulated secretion } \\
\hline 30-minute output (mEq.) & $17 \cdot 2$ & $16 \cdot 8$ & 29.9 & $21 \cdot 2$ & $21 \cdot 1$ & 20 & $18 \cdot 8$ & $19 \cdot 0$ & 4 & $16 \cdot 0$ & $15 \cdot 3$ & 3 & $14 \cdot 5$ & $12 \cdot 4$ & 3 \\
\hline 30-minute volume (ml.) & 142 & 146 & 216 & 176 & 180 & 25 & 160 & 165 & 5 & 142 & 122 & 5 & 137 & 118 & 2 \\
\hline 60-minute output (mEq.) & 30.9 & $30 \cdot 0$ & $56 \cdot 6$ & $39 \cdot 3$ & $38 \cdot 8$ & 16 & $36 \cdot 0$ & $35 \cdot 1$ & 2 & $28 \cdot 4$ & $27 \cdot 4$ & 0 & $26 \cdot 0$ & $24 \cdot 0$ & 2 \\
\hline 60-minute volume (ml.) & 264 & 258 & 417 & 327 & 332 & 17 & 308 & 312 & 5 & 254 & 232 & 1 & 242 & 234 & 2 \\
\hline $\begin{array}{l}\text { One and three-quarter } \\
\text { hour output (mEq.) } \\
\text { One and three-quarter }\end{array}$ & $47 \cdot 6$ & $46 \cdot 4$ & $89 \cdot 6$ & $61 \cdot 7$ & $60 \cdot 6$ & 15 & $57 \cdot 3$ & $56 \cdot 1$ & 2 & $44 \cdot 3$ & $42 \cdot 4$ & 0 & $40 \cdot 2$ & $38 \cdot 8$ & 2 \\
\hline $\begin{array}{l}\text { hour volume (ml.) } \\
\text { Mean concentration }\end{array}$ & 420 & 422 & 695 & 521 & 518 & 15 & 510 & 504 & 2 & 402 & 368 & 1 & 383 & 379 & 2 \\
\hline (mEq./l.) & 109 & 120 & 146 & 116 & 117 & 1 & 116 & 117 & 1 & 108 & 109 & 1 & 96 & 96 & $\mathbf{0}$ \\
\hline (mEq./1.) & 123 & 131 & 152 & 128 & 130 & 2 & 128 & 129 & 1 & 119 & 123 & 0 & 108 & 102 & 0 \\
\hline
\end{tabular}

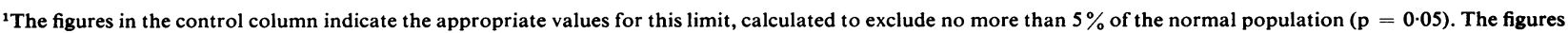
in the other columns indicate the number of patients with values above this level.

TABLE V

SUMMARY OF PREVIOUS STUDIES OF GASTRIC ACID SECRETION IN MEN

\begin{tabular}{|c|c|c|c|c|c|c|c|c|c|c|c|c|}
\hline \multirow[t]{2}{*}{ Reference } & \multicolumn{3}{|c|}{$\begin{array}{l}\text { Basal Acid Output } \\
\text { (mEq./hour) }\end{array}$} & \multicolumn{3}{|c|}{$\begin{array}{l}\text { Basal Volume } \\
\text { (ml.|hour) }\end{array}$} & \multicolumn{3}{|c|}{$\begin{array}{l}\text { Peak 30-min. Output } \\
(m E q .)\end{array}$} & \multicolumn{3}{|c|}{$\begin{array}{l}\text { Peak 30-min. Volume } \\
(\mathrm{ml} .)\end{array}$} \\
\hline & Normal & $\begin{array}{l}\text { Duo- } \\
\text { denal } \\
\text { Ulcer }\end{array}$ & $\begin{array}{l}\text { Gastric } \\
\text { Ulcer }\end{array}$ & Normal & $\begin{array}{l}\text { Duo- } \\
\text { denal } \\
\text { Ulcer }\end{array}$ & $\begin{array}{l}\text { Gastric } \\
\text { Ulcer }\end{array}$ & Normal & $\begin{array}{l}\text { Duo- } \\
\text { denal } \\
\text { Ulcer }\end{array}$ & $\begin{array}{l}\text { Gastric } \\
\text { Ulcer }\end{array}$ & Normal & $\begin{array}{l}\text { Duo- } \\
\text { denal } \\
\text { Ulcer }\end{array}$ & $\begin{array}{l}\text { Gastric } \\
\text { Ulcer }\end{array}$ \\
\hline $\begin{array}{l}\text { Levin, Kirsner, and Palmer } \\
\quad(1951) \\
\text { Lopes, Palmer, and Kirsner }\end{array}$ & $2 \cdot 6$ & $6 \cdot 0$ & $2 \cdot 3$ & 79 & 110 & 81 & & & & & & \\
\hline $\begin{array}{l}(1959) \\
\text { Grossman (1960) }\end{array}$ & $\begin{array}{l}2 \cdot 0 \\
1 \cdot 4\end{array}$ & $\begin{array}{l}5 \cdot 3 \\
2 \cdot 8\end{array}$ & $1 \cdot 3$ & 75 & 117 & 192 & $6 \cdot 0^{1,2}$ & $10 \cdot 0^{1,2}$ & $7 \cdot 0^{1,2}$ & $78^{1,2}$ & $110^{1,2}$ & $96^{1,2}$ \\
\hline Sircus (1960) & $2 \cdot 5$ & $6 \cdot 0$ & $2 \cdot 1$ & & & & $11 \cdot 2^{2}$ & $18 \cdot 8^{2}$ & $7 \cdot 3^{2}$ & & & \\
\hline Baron $(1963 a, b, c)$ & $1 \cdot 3$ & $3 \cdot 6$ & 1.9 & 39 & 62 & 45 & $10 \cdot 8$ & $21 \cdot 0$ & $11 \cdot 3$ & 107 & 176 & 118 \\
\hline $\begin{array}{l}\text { Correia and Moura (1963) } \\
\text { Grossman et al. (1963) }\end{array}$ & $4 \cdot 0$ & $11 \cdot 5$ & & & & & $8 \cdot 1^{2}$ & $18 \cdot 1^{2}$ & & & & \\
\hline $\begin{array}{l}\text { Grossman et al. (1963) } \\
\text { Marks et al. (1963) }\end{array}$ & $\begin{array}{l}2 \cdot 4 \\
4 \cdot 2\end{array}$ & $\begin{array}{l}5 \cdot 3 \\
7 \cdot 1\end{array}$ & $\begin{array}{l}1 \cdot 5 \\
4 \cdot 3\end{array}$ & & & & $\begin{array}{c}5 \cdot 8^{1,2} \\
11 \cdot 3^{2}\end{array}$ & $\begin{array}{l}10 \cdot 0^{1,2} \\
17 \cdot 6^{2}\end{array}$ & $\begin{array}{l}4 \cdot 8^{1,2} \\
9 \cdot 8^{2}\end{array}$ & & & \\
\hline $\begin{array}{l}\text { Marks et al. (1963) } \\
\text { Present study }\end{array}$ & $\begin{array}{l}4 \cdot 2 \\
1.8\end{array}$ & $\begin{array}{l}1 \cdot 1 \\
2 \cdot 1\end{array}$ & $\begin{array}{l}4 \cdot 3 \\
1 \cdot 5\end{array}$ & 58 & 64 & 50 & $17 \cdot 2$ & 21.2 & $14 \cdot 5$ & 142 & 176 & 137 \\
\hline
\end{tabular}

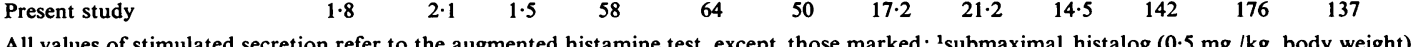
and the present study. ${ }^{2} \frac{1}{2}$ maximal acid output.

None of the indices of acid secretion used in this study showed a significant age trend, thus differing from previous reports (Kirsner and Ford, 1955; Baron, 1963a; Grossman et al., 1963) (Table VI and Fig. 2).

Patients With DUODENAL UlCER Patients with duodenal ulcer older than 60 years secreted less than the remainder of the group (Table VI).

Basal secretory patterns of patients with duodenal ulcer were similar to the controls. An equal proportion (10\%) of patients with duodenal ulcer and controls showed a poor response to histalog (less than $10 \mathrm{mEq}$. in 30 minutes), but patients with duodenal ulcer secreted significantly larger mean volumes of gastric juice than the controls (Fig. 3) and a small, but significant proportion of patients with duodenal ulcer secreted more than any control subjects (Fig. 4 and Tables IV and VIII). Neither peak nor mean concentration of acid in patients with duodenal ulcer differed significantly from the control values.

The secretory patterns of patients with acute duodenal ulcers did not differ significantly from those with chronic ulcer (Table VII). Patients with chronic ulcers were divided into an 'intermittent' group with long intervals between symptoms and a 'recurrent' group with symptoms at least once a year and more than one period of hospitalization; a significantly higher mean acid output was found in 
TABLE VI

INFLUENCE OF AGE ON GASTRIC SECRETORY RESPONSE

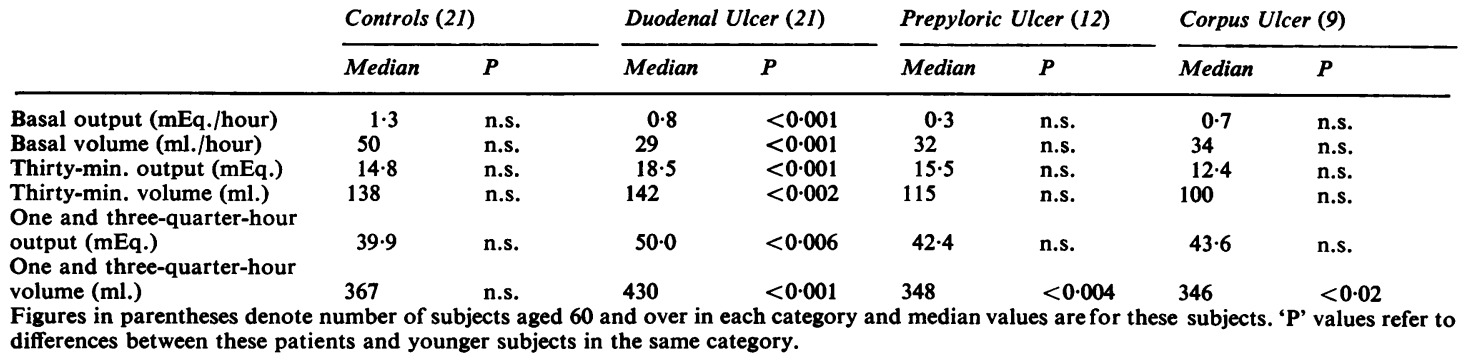

patients with more severe symptoms, but both categories showed a wide range (Table VII). A history of haematemesis was not associated with acid output significantly different from the remainder of the patients with duodenal ulcer, but patients whose duodenal ulcer had perforated at some time had a significantly higher mean rate of acid secretion. The patients who required surgical treatment for duodenal ulcer had secretory tests carried out in connexion with another study, after a decision to operate had been made on clinical grounds, such as history of perforation, recurrent or persistent bleeding, or repeated admission to hospital. Mean peak response to histalog in this group was significantly greater than that of the unoperated patients with duodenal ulcer, but again the ranges overlapped.

PATIENTS WITH CONCURRENT GASTRIC AND DUODENAL ULCERS These patients had radiological findings diagnostic of both gastric and duodenal ulcers in studies done within 10 days of the secretory tests.
The secretory patterns were similar in all respects to patients with duodenal ulcer alone (Tables IV and VIII).

No difference in the response to histalog was found whether the gastric ulcer was situated in the antrum or in the body of the stomach.

PATIENTS WITH PREPYLORIC ULCERS Basal acid output, volume of gastric juice, and concentration of acid were lower in patients with prepyloric ulcer than in controls (Tables IV and VIII). However, following stimulation with histalog, secretory patterns were very similar in control subjects, differing only in lower mean concentration.

PATIENTS WITH ULCERS OF THE BODY OF THE STOMACH Both basal and stimulated secretion of acid of most of the patients with corpus ulcer was significantly less than for control subjects, due especially to lower concentration of acid in the gastric aspirate (Tables IV and VIII). However, some of the patients

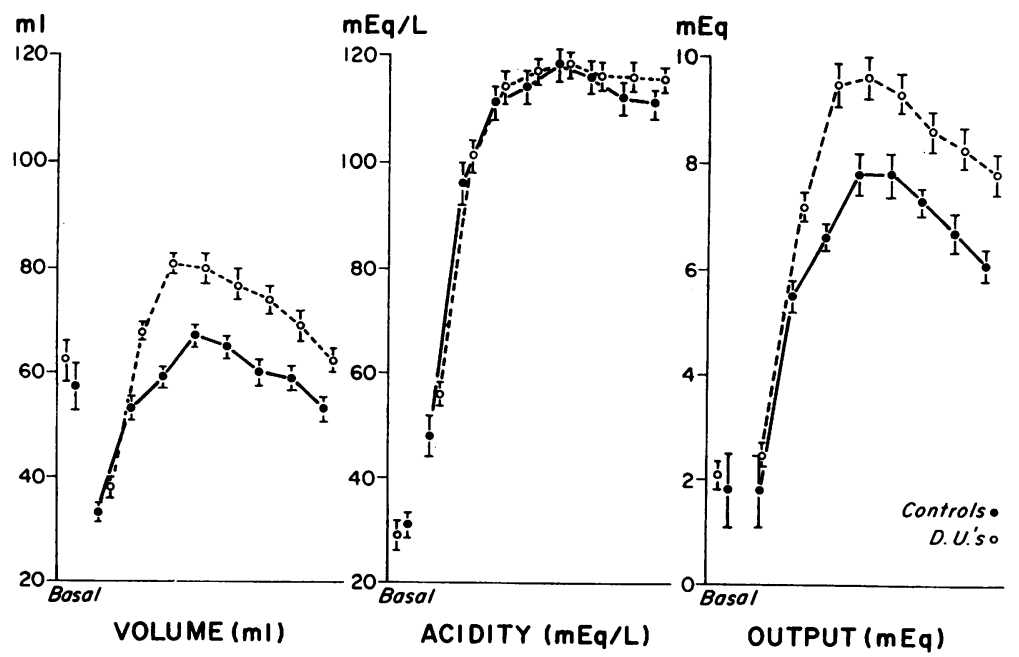

FIG. 3. Mean values and standard errors for 75 control patients and 117 patients with duodenal ulcer during the basal hour and eight 15-minute periods of histalog test. The figures show the tendency for acid output to level off and then fall away in both groups of patients.

The differences in acid output were attributable to the different volumes of gastric juice secreted by the two groups, since there was no significant difference in the concentration of acid during the course of the test. The low basal output in the two groups is due to the low basal acidity. 


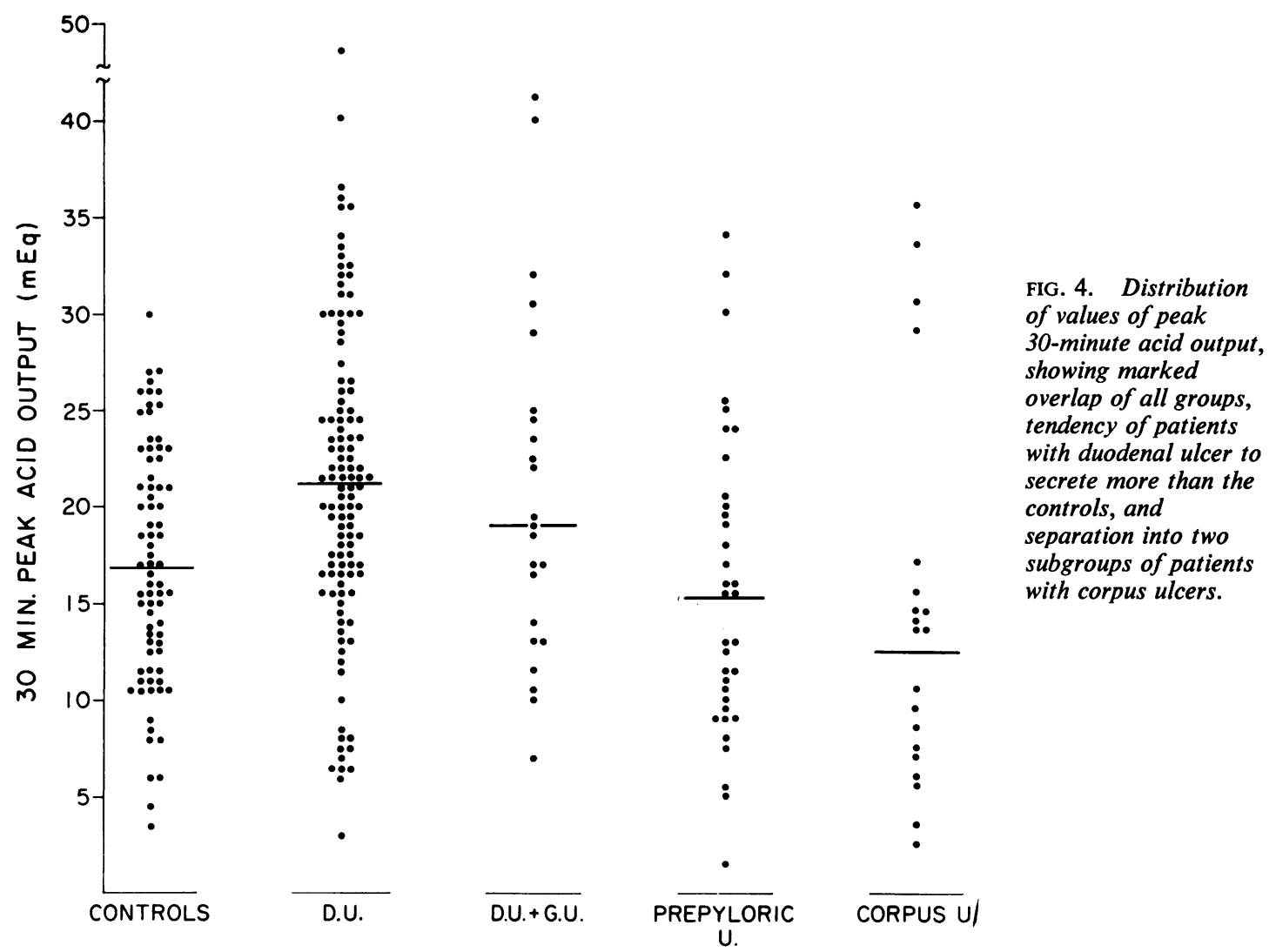

TABLE VII

BASAL AND PEAK 30-MINUTE ACID OUTPUT OF SUBGROUPS OF DUODENAL ULCER POPULATION

\begin{tabular}{|c|c|c|c|c|c|c|}
\hline & \multirow[t]{2}{*}{ No. of Patients } & \multicolumn{2}{|c|}{ Basal Output (mEq.) } & \multicolumn{2}{|c|}{ Peak 30-min. Output (mEq.) } & \multirow[t]{2}{*}{$\boldsymbol{P}$} \\
\hline & & Range & Median & Range & Median & \\
\hline $\begin{array}{l}\text { Duodenal ulcer } \\
+ \text { haematemesis } \\
\text { + perforation } \\
+ \text { surgery }\end{array}$ & $\begin{array}{r}117 \\
39 \\
13 \\
16^{1}\end{array}$ & $\begin{array}{l}0-16 \cdot 5 \\
0-9 \cdot 9 \\
0-10 \cdot 1 \\
0-15 \cdot 8\end{array}$ & $\begin{array}{l}1 \cdot 4 \\
1 \cdot 3 \\
2 \cdot 2 \\
2 \cdot 7\end{array}$ & $\begin{array}{r}3 \cdot 1-48 \cdot 5 \\
6 \cdot 3-40 \cdot 2 \\
7 \cdot 3-35 \cdot 7 \\
13 \cdot 9-52 \cdot 2\end{array}$ & $\begin{array}{l}21 \cdot 1 \\
21 \cdot 1 \\
24 \cdot 4 \\
31 \cdot 3\end{array}$ & $\begin{array}{l}<\overline{0} \\
<0.005\end{array}$ \\
\hline $\begin{array}{l}\text { Duodenal ulcer } \\
\text { Acute } \\
\text { Chronic }\end{array}$ & $\begin{array}{l}25 \\
80\end{array}$ & $\begin{array}{l}0-4 \cdot 3 \\
0-16 \cdot 5\end{array}$ & $\begin{array}{l}0.8 \\
1 \cdot 4\end{array}$ & $\begin{array}{l}3 \cdot 1-36 \cdot 6 \\
6 \cdot 3-48 \cdot 5\end{array}$ & $\begin{array}{l}18 \cdot 8 \\
21 \cdot 5\end{array}$ & 0.13 \\
\hline $\begin{array}{l}\text { Duodenal ulcer } \\
\text { Intermittent } \\
\text { Recurrent }\end{array}$ & $\begin{array}{l}15 \\
26\end{array}$ & $\begin{array}{l}0-7 \cdot 1 \\
0-16 \cdot 5\end{array}$ & $\begin{array}{l}1.0 \\
1.8\end{array}$ & $\begin{array}{l}6 \cdot 4-33 \cdot 9 \\
7 \cdot 3-36 \cdot 1\end{array}$ & $\begin{array}{l}17 \cdot 5 \\
23 \cdot 0\end{array}$ & 0.024 \\
\hline
\end{tabular}

'The only subgroup which is not from the consecutive series of 117 patients with duodenal ulcer in this study. The 'P' values indicate the significance of the difference of peak acid output for each subgroup compared with the first subgroup in each category.

with corpus ulcer had secretory responses greater than normal and comparable with the upper range of patients with duodenal ulcer (Fig. 4).

\section{DISCUSSION}

The basal output in both controls and patients with duodenal ulcer was considerably lower in this study and in a previous study from this hospital (Grossman
1960) than in other reports from America, Europe, or South Africa (Table V). We are unable to explain this discrepancy, which is perhaps due to our selected population. Satisfactory recovery of gastric juice was demonstrated with phenol red marker; moreover, the volumes of basal secretion were similar to values reported in other studies, while the volumes of gastric juice after stimulation were considerably greater than in previous reports 
TABLE VIII

PROBABILITY VALUES OF DIFFERENCES IN GASTRIC SECRETORY DATA FROM SPECIFIED GROUPS OF SUBJECTS

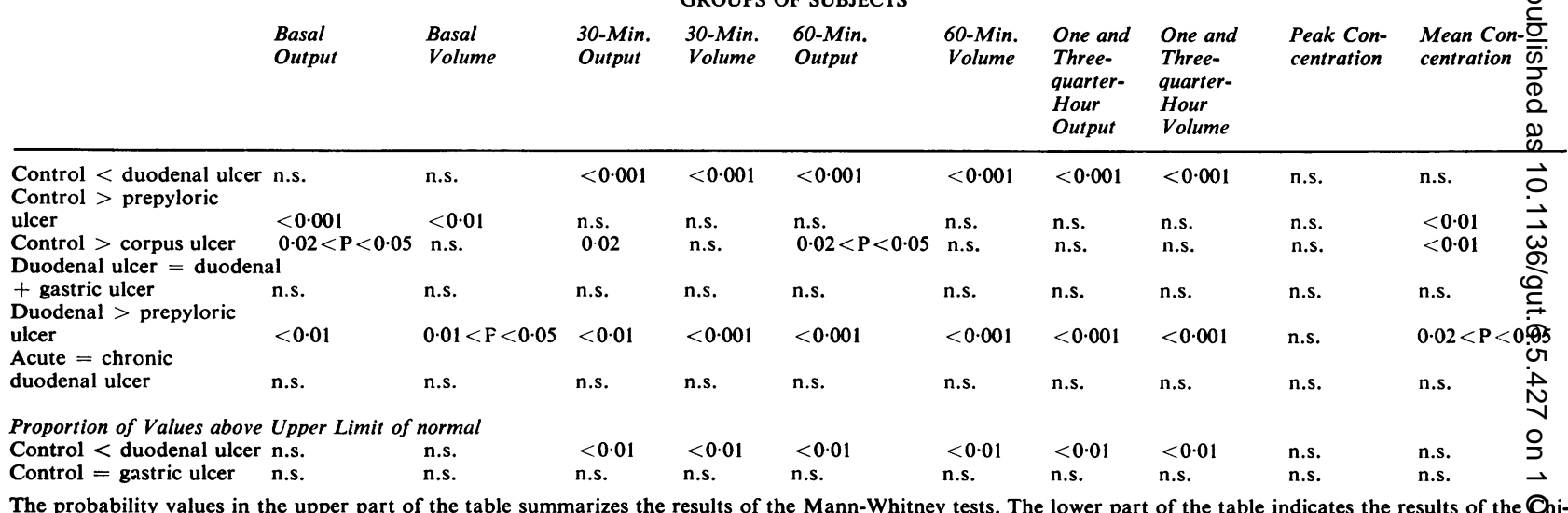

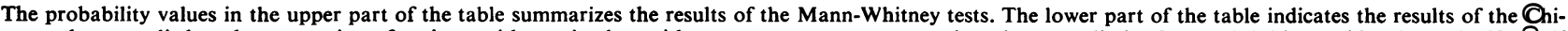


greater than 0.05 . The direction of the difference between the respective groups is shown in the left hand column.

(Table V). Our low values for basal output were due to low acid concentration of the basal aspirate, not only in the control group (four anacid), but also among the patients with duodenal ulcer (13 anacid). While anacidity of basal secretion had been noted previously in both normal subjects (Kirsner and Ford, 1955) and patients with duodenal ulcer (Littman, 1962; Baron, 1963b; Orr, 1964), its occurrence in patients with duodenal ulcer had been denied (Bruce, Card, Marks, and Sircus, 1959; Grossman et al., 1963), or attributed to the presence of an acute complication such as recent bleeding (Chandler and Watkinson, 1959), or found to follow severe and protracted episodes of the disease (Littman, 1962). The latter two criteria accounted for just over half of our patients with duodenal ulcer with anacid basal juice. Basal acidity bore no relationship to the volume of juice aspirated during the basal hour in any of the groups of patients.

In this study, basal output of gastric juice from patients with duodenal ulcer did not differ in range or distribution from the controls, quite unlike the basal hypersecretion noted in patients with duodenal ulcer in many previous reports. The basal secretion of our patients with gastric ulcer was significantly less than control values, contrary to earlier reports of normal basal acid output in such patients (Table V).

Weak, but statistically significant correlation was noted between the basal and peak stimulated output of acid in all groups of patients and at all levels of acid output (Fig. 5 and Table IX), as noted previously by Hunt and Kay (1954), Kirsner and Ford (1955), and Marks (1961). Moreover, our results confirm that patients with greater response to stimulation tend to secrete larger volumes of basal juice than patients whose response to histalog is less (Table $\mathrm{X}$ ). Unlike Sircus (1960) and Baron (1963b), but like Hunt and Kay (1954), we found that the ratio of basal to peak acid output was similar in control subjects and in patients with duodenal ulcer (Table XI). Further, the ratio of basal to peak acid output

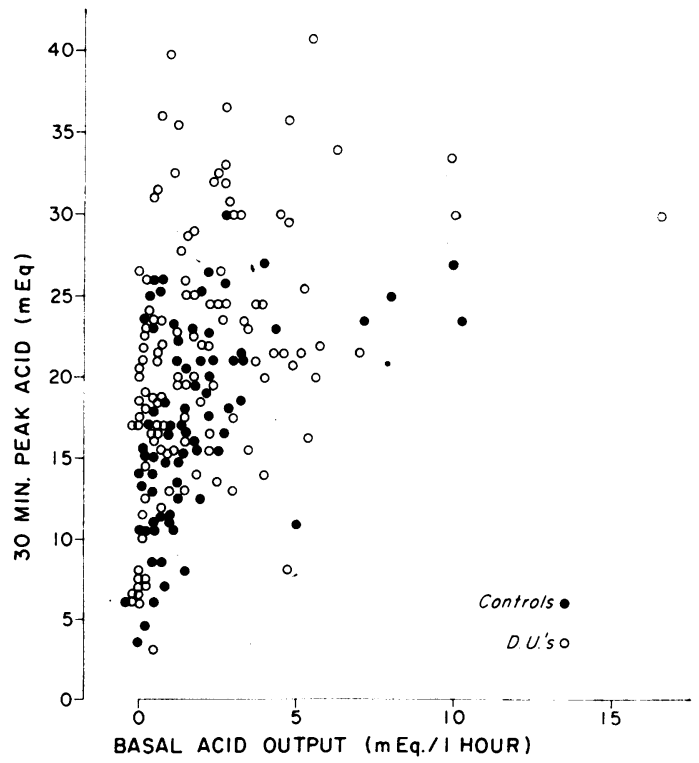

FIG. 5. Relationship of stimulated to basal secretion in controls and patients with duodenal ulcer, showing low values of peak 30-minute output in some patients with low basal output and tendency of peak 30-minute output to be more uniformly high as basal output increases. 


\section{TABLE IX}

CORRELATION BETWEEN SOME OF THE PARAMETERS OF GASTRIC SECRETION



rose as the response to histalog increased (Table XII) but the increase in our patients was not significant, a conclusion similar to that reached by Hunt, Kay, Card, and Sircus (1963), who had calculated that the percentage of the 'maximal' capacity occupied by basal secretion was similar at each level of maximal secretion. Sircus (1960) had suggested that an increase in the ratio of basal to stimulated secretion denoted an increased 'drive' or increased responsiveness of the parietal cell mass, but our results implied that the patients with the low ratios and low basal output had the more significant abnormality of function. We found no group with dissociation between basal and peak acid output, attributable to excessive vagal activity in the basal state (Sircus, 1960; Baron, 1963b; Orr, 1964). Our finding that basal anacidity or hypoacidity is associated with low concentration of acid in stimulated gastric secretion (Table $\mathrm{X}$ ), in all categories of patients, seems comparable to the report of Ball (1961) that patients with gastric ulcer and nocturnal anacidity secrete little acid on stimulation of the stomach. Mucosal defects such as 'gastritis' may be responsible for this type of abnormally low secretory response (Bock, Richards, and Witts, 1963; Krentz, 1964) resulting perhaps from rapid leakage rather than failure of secretion of hydrogen ions (Davenport, Warner, and Code, 1964).

The present study has shown even more overlap between acid output of the control population and patients with peptic ulcer than previous studies using histamine (Bruce et al., 1959; Grossman, 1960; Marks, 1961; Baron, 1963a; Marks, Bank, Moshal, and Louw, 1963) or submaximal doses of histalog (Grossman et al., 1963). The hypersecretors with duodenal or gastric ulcer produced an excessive volume of gastric juice, with concentration not different from normal, presumably by means of an increased parietal cell mass (Card and Marks, 1960), while patients of all groups with impaired secretory

TABLE X

MEAN VALUES OF BASAL SECRETION RELATED TO MAGNITUDE OF PEAK SECRETION

\begin{tabular}{|c|c|c|c|c|c|}
\hline & Controls & Duodenal Ulcer & $\begin{array}{l}\text { Duodenal }+ \\
\text { Gastric Ulcer }\end{array}$ & $\begin{array}{l}\text { Prepyloric } \\
\text { Ulcer }\end{array}$ & Corpus Ulcer \\
\hline Peak 30-min. output ( $\mathrm{mEq}$.) & \multicolumn{5}{|c|}{ Mean basal output (mEq./hour) } \\
\hline$<10$ & 0.5 & 0.5 & - & $0 \cdot 3$ & 0.6 \\
\hline $10-19$ & $1 \cdot 3$ & $1 \cdot 3$ & $1 \cdot 2$ & 0.9 & $1 \cdot 3$ \\
\hline $20-29$ & $2 \cdot 9$ & $2 \cdot 4$ & $2 \cdot 5$ & $1 \cdot 8$ & $3 \cdot 4$ \\
\hline$>30$ & - & $3 \cdot 9$ & $3 \cdot 1$ & $4 \cdot 5$ & $3 \cdot 6$ \\
\hline Peak 30-min. volume $(\mathrm{ml})$. & \multicolumn{5}{|c|}{ Mean basal volume (ml./hour) } \\
\hline$<100$ & 58 & 43 & 14 & 33 & 25 \\
\hline 100-199 & 64 & 66 & 61 & 44 & 64 \\
\hline 200-299 & 91 & 79 & 62 & 81 & 64 \\
\hline$>300$ & - & 134 & 84 & - & 90 \\
\hline Mean concentration (mEq./l.) & \multicolumn{5}{|c|}{ Mean basal concentration ( $m E q . \mid l)}$. \\
\hline$<100$ & 17 & 11 & - & 13 & 11 \\
\hline$>120$ & 44 & 40 & - & 29 & 24 \\
\hline
\end{tabular}

TABLE XI

MEAN RATIOS OF SECRETORY INDICES ${ }^{1}$

Controls Duodenal Ulcer $\begin{aligned} & \text { Duodenal }+ \\ & \text { Gastric Ulcer }\end{aligned} \quad \begin{aligned} & \text { Prepyloric Ulcer } \\ & \text { Ulcerpus Ulcer }\end{aligned}$

\begin{tabular}{|c|c|c|c|c|c|}
\hline \multicolumn{6}{|l|}{ Output } \\
\hline Basal/peak $30 \mathrm{~min}$. & $0 \cdot 10$ & $0 \cdot 10$ & $0 \cdot 08$ & 0.08 & $0 \cdot 12$ \\
\hline Peak $60 \mathrm{~min} . /$ peak $30 \mathrm{~min}$. & $1 \cdot 82$ & $1 \cdot 84$ & $1 \cdot 79$ & $1 \cdot 79$ & $1 \cdot 79$ \\
\hline One and three-quarter-hour/peak $30 \mathrm{~min}$. & $2 \cdot 82$ & $2 \cdot 85$ & $2 \cdot 80$ & $2 \cdot 75$ & $2 \cdot 76$ \\
\hline \multicolumn{6}{|l|}{ Volume } \\
\hline Basal/peak $30 \mathrm{~min}$. & 0.40 & $0 \cdot 37$ & 0.38 & 0.35 & 0.38 \\
\hline Peak $60 \mathrm{~min} . /$ peak $30 \mathrm{~min}$. & 1.88 & $1 \cdot 86$ & 1.83 & $1 \cdot 79$ & $1 \cdot 81$ \\
\hline One and three-quarter-hour/peak $30 \mathrm{~min}$. & 3.02 & $2 \cdot 91$ & $2 \cdot 86$ & $2 \cdot 85$ & $2 \cdot 84$ \\
\hline
\end{tabular}

${ }^{1}$ The figures denote the mean ratios of secretory data indicated in the left hand column. 


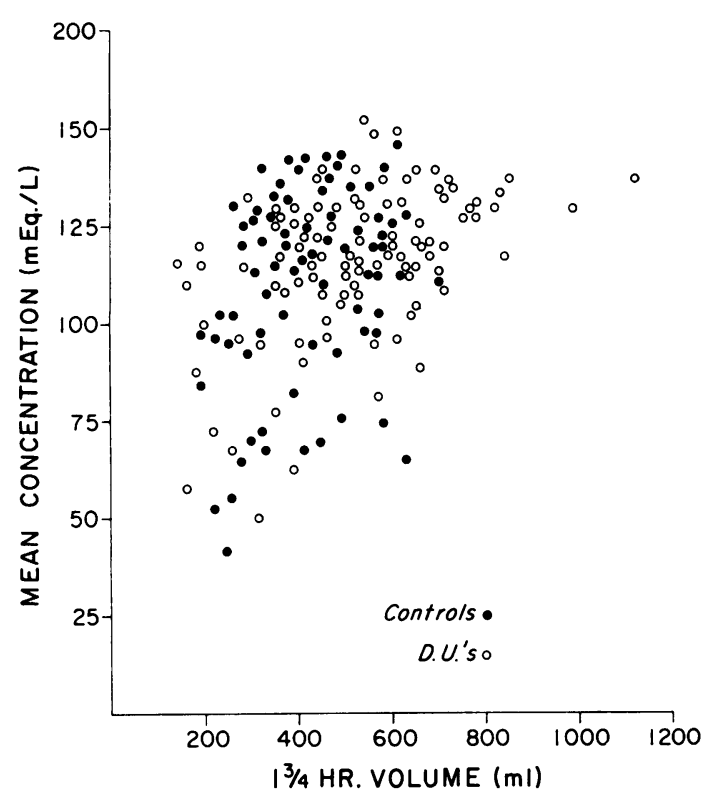

FIG. 6. Relationship between total volume of gastric juice produced during the test and mean concentration of acid, showing that low concentration was associated with low volumes of secretion, although the converse was not necessarily true.

responses produced small volumes of gastric juice, often with low concentration of acid (Fig. 6). Patients with duodenal ulcer with low peak output were unable to sustain secretion of acid for the duration of the test as well as the controls or the remainder of the patients with duodenal ulcer (Table XII) and also tended to secrete basal juice with low acid concentration. The aetiological significance of these findings is not clear, but low acid output in these patients could not be correlated with age, duration of the disease, complications such as haemorrhage or presence of concurrent gastric ulcer. Gastric secretion in patients with coincident duodenal and gastric ulcers did not differ from patients with simple duodenal ulcer, as

\section{TABLE XII}

MEAN RATIOS OF BASAL OUTPUT TO PEAK 30-MIN. OUTPUT RELATED TO MAGNITUDE OF PEAK SECRETION

\begin{tabular}{lcc}
$\begin{array}{l}\text { Peak } 30-\text { minute Output } \\
\text { (mEq.) }\end{array}$ & \multicolumn{2}{c}{ Mean Ratios } \\
\cline { 2 - 3 } & Controls & Duodenal Ulcer \\
\hline$<10$ & $0 \cdot 07^{1}$ & $0 \cdot 07^{2}$ \\
$10-19$ & $0 \cdot 10$ & $0 \cdot 08$ \\
$20-29$ & $0 \cdot 12$ & $0 \cdot 10$ \\
$>30$ & - & $0 \cdot 13$ \\
'Three of eight patients had basal anacidity. & \\
'Eight of 12 patients had basal anacidity.
\end{tabular}

noted previously by Marks and Shay (1959) and Grossman (1960), although other reports (Ball, 1961; Baron, 1963a) had noted that secretion was less in patients with combined ulcers. As in previous reports (Hunt and Kay, 1954; Baron, 1963a; Grossman et al., 1963), we found no correlation between the acid output and length of clinical history of the duodenal ulcer, but we were able to show that patients whose duodenal ulcer was a serious clinical problem, especially if sufficient to require surgery, had a significantly higher mean rate of acid secretion than patients whose duodenal ulcer was clinically less troublesome. Our results indicate that measurement of gastric acid secretion may help in assessing the prognosis of ulcer disease, but a prospective study will be necessary for confirmation.

In this investigation, patients with prepyloric ulcer showed secretory patterns similar to the controls, as noted previously by Marks and Shay (1959), thus differing from both patients with duodenal ulcer and ulcer of the remainder of the stomach. The functional differences between the two types of gastric ulcer suggest the presence of more severe degrees of gastric mucosal abnormality in patients with corpus ulcers.

Most of the patients with ulcer of the body of the stomach produced less gastric juice, both during the basal period and after stimulation, than did the controls. Moreover, the gastric aspirate from these patients contained very significantly lower concentrations of acid. Nevertheless, some of the patients with corpus ulcer showed no evidence of secretory impairment and actually produced more acid than normal. These patients were not clinically different from those with impaired secretion and coincident duodenal ulcer was excluded at operation. The sharp separation, without overlap, of these types of secretory pattern in patients with corpus ulcer suggests that this group is not aetiologically homogeneous. Marks and Shay (1959) had shown a similar range of secretion in patients with gastric ulcer, although they did not describe such sharp separation as in our series, perhaps due to differences in technique or vagaries in the selection of patients.

Histalog, in the dose used in this study, was found to be a very satisfactory gastric secretory stimulant. Side effects were not noted, apart from a sensation of warmth accompanied by flushing. Secretion was well sustained, higher than in any previous report and repeatability was excellent. The peak 30 -minute response was used for most of the comparisons and calculations in this investigation, since separation of the different categories of patients was not improved by use of peak 60 -minute or one-and-three-quarterhour values (Table XIII). 


\section{TABLE XIII}

MEAN RATIOS OF ONE AND THREE-QUARTER-HOUR OUTPUT TO PEAK 30-MINUTE OUTPUT IN PATIENTS WITH DUODENAL ULCER

\begin{tabular}{l}
$\begin{array}{l}\text { Peak } \\
\text { 30-minute Output } \\
\text { (mEq.) }\end{array}$ \\
\hline$<10 \quad>30 \quad P$
\end{tabular}

Mean ratio ${ }^{1}$

$1 \frac{3}{4}$ hour/peak $30 \mathrm{~min}$. output

$2.72 \quad 2.94<0.01$

${ }^{1}$ The values of the ratios indicate that patients who secrete more than the upper limit of normal sustain secretion significantly better than patients with a poor response to histalog.

\section{SUMMARY}

Histalog, in a dose of $1.5 \mathrm{mg}$. per $\mathrm{kg}$. body weight, has provided a safe and repeatable means of eliciting maximal gastric stimulation. However, owing to the marked overlap of secretory responses, distinction between different diagnostic categories of patients has been unsatisfactory. Although patients with duodenal ulcer tended to secrete more than control subjects, only one sixth secreted more than the upper limit of normal (30 mEq. in 30 minutes) while $10 \%$ of patients of both groups showed a poor response (less than $10 \mathrm{mEq}$. in 30 minutes). Patients whose duodenal ulcer was a severe clinical problem, especially those requiring surgery, secreted acid at a significantly higher mean level than patients whose ulcer was clinically less troublesome. Patients with gastric ulcer, particularly when situated in the body of the stomach, tended to secrete less acid than the controls, but a few showed the same degree of hypersecretion in patients with duodenal ulcer.

In this study, basal secretion was lower and stimulated secretion greater than in previous reports. Some correlation between basal and stimulated secretion was noted in all groups of patients. Patients whose response to histalog was small and poorly sustained, with low concentration of acid, secreted small volumes of juice during the basal hour, while those with normal or excessive response to histalog tended to secrete well during the basal period.

From our results, we have been unable to define the pathophysiological basis of duodenal ulcer, except to suggest that increased parietal cell mass is unlikely to be the sole, or perhaps even the most important determinant, in many patients. Instead, we have been able to show that impaired secretory capacity, suggesting gastric mucosal damage, is associated with peptic ulcer in a considerable proportion of patients of all categories.

\section{REFERENCES}

Ball, P. A. J. (1961). The secretory background to gastric ulcer. Lancet, 1, 1363-1365.
Baron, J. H. (1963a). An assessment of the augmented histamine test in the diagnosis of peptic ulcer. Gut, 4, 243-253.

- (1963b). The relationship between basal and maximum acid output in normal subjects and patients with duodenal ulcer. Clin. Sci., 24, 357-370.

- (1963c). Studies of basal and peak acid output with the augmented histamine test. Gut, 4, 136-144.

Bartlett, M. S. (1949). Fitting a straight line when both variables are subject to error. Biometrics, 5, 207-212.

Bock, O. A. A., Richards, W. C. D., and Witts, L. J. (1963). The relationship between acid secretion after augmented histamine stimulation and the histology of the gastric mucosa. Gut, 4, 112-114.

Bruce, J., Card, W. I., Marks, I. N., and Sircus, W. (1959). The rationale of selective surgery in the treatment of duodenal ulcer. J. roy. Coll. Surg. Edinb., 4, 85-104.

Card, W. I., and Marks, I. N. (1960). The relationship between the acid output of the stomach following 'maximal' histamine stimulation and the parietal cell mass. Clin. Sci., 19, 147-163.

Chandler, G. N., and Watkinson, G. (1959). The early diagnosis of the causes of haematemesis. Quart. J. Med., 28, 371-395.

Correia, J. P., and Moura, M. C. de (1963). Clinical experience with the augmented histamine test, with special emphasis on patients with gastrectomy. Gastroenterologia (Basel), 99, 30-44.

Davenport, H. W., Warner, H. A., and Code, C. F. (1964). Functional significance of gastric mucosal barrier to sodium. Gastroenterology, 47, 142-152.

Grossman, M. I. (1960). The pathologic physiology of peptic ulcer. Amer. J. Med., 29, 748-753.

- Kirsner, J. B., and Gillespie, I. E. (1963). Basal and histalogstimulated gastric secretion in control subjects and in patients with peptic ulcer or gastric cancer. Gastroenterology, 45, 14-26.

Herrera, L. (1958). The precision of percentiles in establishing normal limits in medicine. J. Lab. clin. Med., 52, 34-42.

Hunt, J. N., and Kay, A. W. (1954). The nature of gastric hypersecretion of acid in patients with duodenal ulcer. Brit. med.J., 2, 1444-1446.

,$- \frac{2,1444-1446 .}{-}$ Card, W. I., and Sircus, W. (1963). The nature of basal hypersecretion of acid in man with duodenal ulcer. In Pathophysiology of Peptic Ulcer, edited by S. C. Skoryna, pp. 333-337. McGill University Press, Montreal.

Kirsner, J. B., and Ford, H. (1955). The gastric secretory response to Histalog: one-hour basal and Histalog secretion in normal persons and in patients with duodenal ulcer and gastric ulcer. J. Lab. clin. Med., 46, 307-311.

Krentz, K. (1964). Untersuchungen über das Sekretionsverhalten der Magenschleimhaut bei chronischer Oberflächengastritis. Dtsch. Arch. klin. Med., 209, 616-628.

Levin, E., Kirsner, J. B., and Palmer, W. L. (1951). A simple measure of gastric secretion in man. Comparison of one hour basal secretion, histamine-secretion and 12 hour nocturnal gastric secretion. Gastroenterology, 19, 88-98.

Littman, A. (1962). Basal gastric secretion in patients with duodenal ulcer; a long term study of variations in relation to ulcer activity. Ibid., 43, 166-173.

Lopes, R. W., Palmer, W. I., and Kirsner, J. B. (1959). Pyloric ulcer with specific reference to gastric secretory pattern. Ibid., 36, 790-795.

Marks, I. N., and Shay, H. (1959). Observations on the pathogenesis of gastric ulcer. Lancet, 1, 1107-1111.

- (1961). The augmented histamine test. Gastroenterology, 41, 599-603.

, Bank, S., Moshal, M. G., and Louw, J.H.(1963). The augmented histamine test. A review of 615 cases of gastroduodenal disease. S. Afr. J. Surg., 1, 53-59.

Orr, I. (1964). Physiological considerations in the surgery of peptic ulcer. Ann. roy. Coll. Surg. Engl., 34, 314-335.

Siegel, S. (1956). Nonparametric Statistics for the Behavioral Sciences. McGraw-Hill, New York.

Sircus, W. (1960). The aetiology of peptic ulcer. In Peptic Ulcer: a Sympsoium for Surgeons, edited by C. Wells and J. Kyle, chapter 2, pp. 11-36. Livingstone, Edinburgh.

Ward, S., Gillespie, I. E., Passaro, E. P., and Grossman, M. I. (1963). Comparison of Histalog and histamine as stimulants for maximal gastric secretion in human subjects and in dogs. Gastroenterology, 44, 620-626.

Zaterka, S., and Neves, D. P. (1964). Maximal gastric secretion in human subjects after histalog stimulation. Comparison with augmented histamine test. Ibid., 47, 251-257. 